\title{
Implication of the JAK-STAT Pathway in Gliomagenesis: A Target for Therapy?
}

Elias A El Habr ${ }^{1 *}$, Christos Adamopoulos ${ }^{2}$, Georgia Levidou ${ }^{1}$, Vassilis Samaras ${ }^{3}$, Athanasios Zisakis ${ }^{3}$, Penelope Korkolopoulou ${ }^{1}$ and Christina Piperi $^{2}$

${ }^{1}$ First Department of Pathology, Laiko Hospital, National and Kapodistrian University of Athens, Medical School, Athens, Greece ${ }^{2}$ Department of Biological Chemistry, National and Kapodistrian University of Athens, Medical School, Athens, Greece

${ }^{3}$ Department of Pathology and Neurosurgery, Red Cross Hospital, Greece

\begin{abstract}
Gliomas, being the most prevalent and aggressive malignancy of the central nervous system, are associated with poor prognosis and very low survival rates. Failure of malignant glioma cells to respond to conventional cancer therapies is attributed to their infiltrating and immunosuppressive phenotype along with increased molecular heterogeneity. Current evidence implicates aberrant JAK-STAT signaling and expression of STAT inhibitors in the molecular pathogenesis of gliomas. This review provides a critical account of recent evidence regarding JAK-STAT signaling components in gliomagenesis, highlighting the potential therapeutic benefits and perspectives of targeting this pathway.
\end{abstract}

Keywords: Malignancy; Gliomagenesis; STAT inhibitors

\section{Introduction}

Gliomas, the most prevalent primary malignancies in the central nervous system, consist of a heterogeneous group of tumors. Depending on the glial cell type they arise from, gliomas can be classified in astrocytoma, oligodendroglioma, ependymoma or in mixed glioma when two or more different cell types are involved. Despite the established treatment, consisting of surgical excision of the tumor followed by chemotherapy and radiotherapy, the survival rate of patients diagnosed with glioblastoma (grade IV astrocytoma, GBM), the most aggressive glioma type, does not exceed 24 months after diagnosis [1]. In patients with solid cancer, such as malignant glioma, the capacity of tumor to generate a tolerant immunosuppressive niche and the activation of a plethora of mechanisms to evade immunosurveillance may result in the annihilation of effective immune responses [2].

After glioma excision, biopsies are analyzed by pathologists using standard criteria in order to determine the type and grade of the tumor. Recently, several investigators have been working on the identification of biomarkers, which will allow the prediction of disease outcome and the design of customized therapy [3]. The generation of phosphorylation state-specific antibodies (PSSAs) recognizing the activated form of several proteins have enabled the observation in situ of the altered signaling cascade of several pathways during tumorigenesis [4]. In the same regard, molecular diagnostics have improved the diagnosis, the prediction and the planning of cancer treatment.

The Janus kinase (JAK)-signal transducer and activator of transcription (STAT) pathway, mainly implicated in mediating signals after cytokine binding, is one of the most investigated signaling pathways in human [5]. In several human disorders, JAKSTAT pathway have been frequently found altered and deregulated, which is due to the complexity and the several interactions with others signaling cascades, such as nuclear factor- $\kappa \mathrm{B}(\mathrm{NF}-\mathrm{kB})$, phosphatidylinositol 3-kinase/AKT/mTOR (PI3K/AKT/mTOR) and mitogen activated protein kinase (MAPK). Moreover, several reports argue that alterations in STAT proteins expression are involved in tumorigenesis. Finally, it has been proposed that in tumors with defective JAK-STAT pathway, cytokine-based immunotherapy could be annihilated [6]. Pharmacological inhibitors targeting the aberrant signaling of JAK-STAT pathway during malignant transformation have been developed for clinical use [5].

The aim of the current review is to summarize and critically discuss the findings of several studies investigating the role of activated JAK-STAT signaling in human gliomas. Reports that used PSSAs for the activated form of JAK-STAT pathway components and/or molecular markers for the same pathway are discussed and an attempt to highlight the role of this pathway in gliomagenesis is undertaken. Finally, we will discuss the results of several reports dealing with new inhibitors targeting this pathway for therapeutic purposes.

\section{The JAK-STAT Pathway: Overview (Figure 1)}

JAK-STAT pathway is the main mediator of signaling of several cytokines and growth factors. Some cell functions, such as proliferation, migration and apoptosis are triggered by JAK [7]. JAKSTAT pathway is stimulated and activated by a variety of ligands and their receptors. This activation results in JAK dimerization followed by the phosphorylation of the receptor cytoplasmic domain in order to "attract" a STAT. The latter, upon phosphorylation, forms a dimer and translocates to the nucleus where it regulates gene expression $[5,7]$. Depending on the type of ligands, the receptor forms homodimers when stimulated for example by growth hormone or heteromultimers when stimulated by interferons (IFN) and interleukins [7]. One major stimulator of the JAK-STAT pathway is the interleukin-6 (IL-6) family. In order to activate JAK after cytokine binding, it is imperative the close apposition and association of its homodimers at the membrane level. STATs are translocated to the membrane through their Src

*Corresponding author: Elias A El-Habr, 75 Mikras Asias street, First Department of Pathology, National and Kapodistrian University of Athens, Medical School, 11527 Athens, Greece; Tel: 0030-210-7462229; Fax: 0030-210-7462157; E-mail: elhabere@yahoo.com

Received February 21, 2013; Accepted April 17, 2013; Published April 19, 2013

Citation: El Habr EA, Adamopoulos C, Levidou G, Samaras V, Zisakis A, et al (2013) Implication of the JAK-STAT Pathway in Gliomagenesis: A Target for Therapy? J Neurol Disord 1: 112. doi:10.4172/2329-6895.1000112

Copyright: (c) 2013 El Habr EA, et al. This is an open-access article distributed under the terms of the Creative Commons Attribution License, which permits unrestricted use, distribution, and reproduction in any medium, provided the original author and source are credited. 
homology 2 (SH2) domains (Figure 2), which bind specific sites of the receptor generated after JAK-mediated phosphorylation. This translocation results in STAT activation, through tyrosine and serine phosphorylation and is followed by the migration of its activated form into the nucleus [5]. Depending on cellular context, the downstream targets of STATs could influence proliferation, migration, and cell survival, thus implicating the aberrant activation of STATs in oncogenesis (Figure 1).

It is well established that several negative intracellular regulators contribute to JAK-STAT pathway inhibition. The three major are the SH2-containing protein tyrosine phosphatase 1 (SHP1), the protein inhibitors of activated STATs (PIAS), and the suppressors of cytokine signaling proteins (SOCS) [8]. These inhibitors are implicated in the knock-down of cytokine signaling at specific steps in the transduction cascade. SHP1 proteins reverse the activity of JAK, whereas SOCS proteins bind phosphorylated JAK, inhibiting its kinase activity, and facilitate also its ubiqitination. Finally, PIASs prevent STAT binding to DNA.

\section{Role of STAT Proteins in Human Gliomas}

Seven different members of STAT proteins (STAT-1, 2, 3, 4, $5 \mathrm{~A}, 5 \mathrm{~B}$, and 6) constitute a family of transcription factors that are localized in the cytoplasm. These proteins contain an $\mathrm{N}$-terminal domain, a coiled-coil domain, a DNA binding site, a linker domain, an $\mathrm{SH} 2$ domain and a transactivation domain (TAD) [9] (Figure 2). Post-translationally STAT proteins can be modified by several mechanisms, but the most frequent change is phosphorylation of a critical tyrosine residue within TAD, which occurs after cytokinereceptor stimulation as described above (Figure 2). This modification

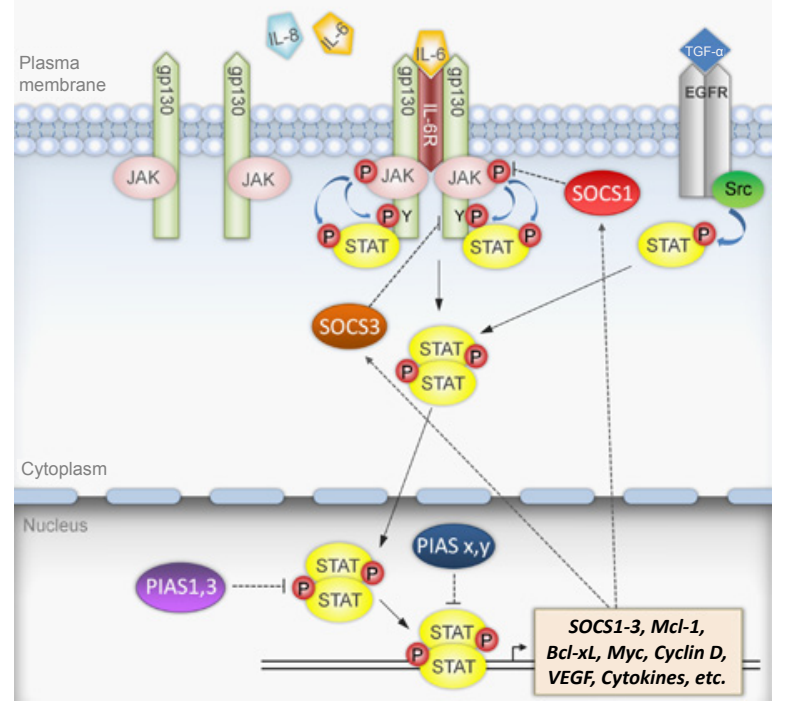

Figure 1: Schematic representation of JAK-STAT signaling pathway.

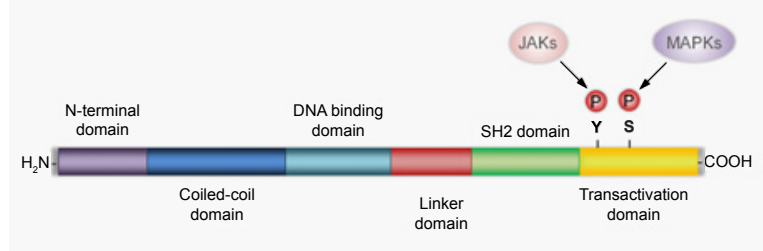

Figure 2: Schematic representation of STAT proteins structure. is essential for the dimerization and the translocation of STAT proteins into the nucleus [10]. An additional site phosphorylated in some STAT family members (STAT-1, $-3,-4,-5 \mathrm{~A}$ and $-5 \mathrm{~B}$ ) and also located in TAD, is a serine residue [11]. The phosphorylation of the latter promotes DNA binding affinity and transcriptional activation. It is noteworthy that the phosphorylation of this serine in STAT-1 and STAT-3 is due to kinases of the MAP pathway (ERKs, JNK and p38) which highlights the important interactions taking place between these two signaling pathways [12] (Figure 2). Finally, the N-terminal domain has been shown to regulate STAT tetramerization, a state allowing the binding of co-activators or co-repressors [9] (Figure 2).

It is well established that STAT-1, with a basic role in IFN signaling, is required in innate immunity and activated by IFN- $\alpha$ and IFN- $\gamma$. Moreover, many growth factors, such as IL- 6 and IL-10, have been shown to activate STAT-1. Within the cell, STAT-1 seems to regulate normal growth control and may behave as a tumor suppressor [13] In 85\% (39/46) of GBM, Haybaeck et al. [14] (Table 1) detected a cytoplasmic immunostaining of STAT-1, suggesting that mainly this protein is present in its inactive form. The same group detected STAT1 expression in reactive astrocytes and in microglial components. These data along with the STAT-1 known role in the regulation of apoptosis and in the interaction with chemotherapeutic drugs led them to suggest a possible role of this protein in the response of GBM to chemotherapeutic agents.

STAT-3 is crucially situated at the intersection points of several signaling cascades, mainly the JAK pathway that becomes activated in response to environmental signals (cytokines, extracellular signals and growth factors) but also the PI3K/AKT, the NF- $\kappa \mathrm{B}$ and the MAPK pathways. Essential for STAT-3 activation is the tyrosine phosphorylation (Tyr705) located within TAD. A second STAT3 phosphorylation residue, serine (Ser727), was also found to be phosphorylated in the conserved Pro-X-Ser-Pro sequence [15].

The clinical and prognostic significance of STAT- 3 and its activated form (phosphorylated STAT-3, p-STAT-3) in human gliomas have been studied by several groups [16-26] (Table 1). Brantley et al. [22] used two different antibodies against p-STAT-3, one for the phosphorylation of tyrosine and the other for the phosphorylation of serine residues. Since most reports used PSSA against tyrosine residue, the latter report along with the report of Riemenschneider et al. [24] were the first to detect a phosphorylation of serine residue in GBM. A point of convergence emerging from all reports dealing with the expression of p-STAT-3 in gliomas is that its immunostaining was mainly nuclear. This finding is in some way expected since it is known that activated STAT-3 translocates to the nucleus where it acts as transcriptional factor. Only two reports $[20,26]$ found except from nuclear, cytoplasmic and/or membranous immunostaining, which could be explained by recent findings, showing that STAT protein is rather forming high molecular mass protein complexes in lipid rafts (localized at the cell surface) than being a single monomer in the cytosol of mammalian cells and/or that STAT-3 dimerizes before its activation and migration into the nucleus [26].

The reported frequency of p-STAT-3 activation ranges between $<9 \%$ [25] and 92\% [17] among the various investigations. This enormous variation is in some way expected since the cohorts used in these investigations are very heterogeneous regarding the ratio of low to high grade tumors and according to the pathologic type of tumor. In the same context, Abou-Ghazal et al. [19] showed that expression of p-STAT-3 was different according to the pathologic type of the tumor, where the presence of highest p-STAT-3 staining was most 
Citation: El Habr EA, Adamopoulos C, Levidou G, Samaras V, Zisakis A, et al. (2013) Implication of the JAK-STAT Pathway in Gliomagenesis: A Target for Therapy? J Neurol Disord 1: 112. doi:10.4172/2329-6895.1000112

Page 3 of 8

\begin{tabular}{|c|c|c|c|c|c|}
\hline $\begin{array}{l}\text { Report (number of cases } \\
\text { and grades) }\end{array}$ & Antibody used & $\begin{array}{l}\text { Immunostaining percent- } \\
\text { age }\end{array}$ & $\begin{array}{l}\text { Correlations with } \\
\text { clinicopathological } \\
\text { features }\end{array}$ & Other correlations & Survival analysis \\
\hline $\begin{array}{l}\text { Tu et al. [16] (96 HAs: } 18 \\
\text { grade II, } 35 \text { III and } 43 \text { IV) }\end{array}$ & $\begin{array}{l}\text { STAT-3 ab (SCB), diluted } \\
\text { 1:25 for IHC and WB }\end{array}$ & $\begin{array}{l}68.75 \%(66 / 96) \text { showed } \\
\text { nuclear and cytoplasmic } \\
\text { staining }\end{array}$ & $\begin{array}{l}\text { STAT-3 with: } \\
\text { - higher grade } \\
\text { - lower KPS score }\end{array}$ & $\begin{array}{l}\text { STAT-3 with: } \\
\text { - JAK-1 } \\
\text { - p-JAK-1 }\end{array}$ & $\begin{array}{l}\text { - STAT-3 associated with a worse } \\
\text { prognosis } \\
\text { - Multivariate analysis: STAT-3 as } \\
\text { an independent prognostic factor }\end{array}$ \\
\hline \begin{tabular}{|l} 
Piperi et al. [17] (97 HAs: \\
20 grade II, 9 III and 68 IV)
\end{tabular} & $\begin{array}{l}\text { Rabbit monoclonal anti-p- } \\
\text { STAT-3 (Tyr705) ab (CST), } \\
\text { diluted 1:50 (IHC) }\end{array}$ & $\begin{array}{l}91.75 \%(89 / 97) \text { showed } \\
\text { nuclear } \\
\text { staining }\end{array}$ & $\begin{array}{l}\text { p-STAT-3 with: } \\
\text { - tumor grade } \\
\text { - present/extent of } \\
\text { necrosis }\end{array}$ & $\begin{array}{l}\text { p-STAT-3 with: } \\
\text { - IL-8 } \\
\text { - MVD } \\
\text { - shape factor }\end{array}$ & $\begin{array}{l}\text { Lower p-STAT-3 with shorter } \\
\text { survival }\end{array}$ \\
\hline $\begin{array}{l}\text { Birner et al. [18] (111 HAs } \\
\text { grade IV/25 gliomas grade } \\
\text { III) }\end{array}$ & $\begin{array}{l}\text { Rabbit monoclonal anti-p- } \\
\text { STAT-3 (Tyr705) ab (CST), } \\
\text { diluted 1:50 (IHC) }\end{array}$ & $\begin{array}{l}76.6 \%(85 / 111) \text { of grade IV } \\
\text { showed nuclear stain- } \\
\text { ing } 60 \% \text { of grade III }\end{array}$ & $\begin{array}{l}\text { No correlation with } \\
\text { tumor grade }\end{array}$ & - & $\begin{array}{l}\text { - } p \text {-STAT-3 positive cells with } \\
\text { survival } \\
\text { - Multivariate analysis: p-STAT-3 as } \\
\text { an independent prognostic factor }\end{array}$ \\
\hline $\begin{array}{l}\text { Abou-Ghazal et al. [19] (73 } \\
\text { HAs: } 3 \text { grade II, } 17 \text { III and } \\
53 \text { IV/ } 56 \text { other gliomas) }\end{array}$ & $\begin{array}{l}\text { Anti-p-STAT-3 (Tyr705) ab } \\
\text { (CST), diluted 1:50 (IHC) }\end{array}$ & $\begin{array}{l}0 \% \text { of grade II, } 53 \%(9 / 17) \\
\text { of III and } 53 \%(32 / 60) \text { of IV } \\
\text { showed nuclear staining }\end{array}$ & $\begin{array}{l}\text { p-STAT-3 with: } \\
\text { - pathologic type of } \\
\text { tumor tumor grade }\end{array}$ & $\begin{array}{l}\text { p-STAT-3 with T-cell } \\
\text { infiltration }\end{array}$ & $\begin{array}{l}\text { p-STAT-3 in AAs as a prognostic } \\
\text { factor in univariate analysis }\end{array}$ \\
\hline $\begin{array}{l}\text { Caldera et al. [20] (54 HAs: } \\
10 \text { grade II, } 10 \text { III and } 34 \\
\text { IV/10 OGs) }\end{array}$ & $\begin{array}{l}\text { Mouse monoclonal anti-p- } \\
\text { STAT-3 (Tyr705) ab (CST), } \\
\text { diluted 1:40 (IHC) }\end{array}$ & $\begin{array}{l}\% \text { of positive cells were } 0 \% \\
\text { of grade II, } 50 \% \text { of III and } \\
56.2 \% \text { of IV showed mainly } \\
\text { nuclear and little } \\
\text { cytoplasmic staining }\end{array}$ & $\begin{array}{l}\text { p-STAT-3 with } \\
\text { tumor grade }\end{array}$ & p-STAT-3 with p-AKT & No significant correlation \\
\hline $\begin{array}{l}\text { Lo et al. [21] (44 HAs: } 24 \\
\text { grade II, } 14 \text { III and } 6 \text { IV) }\end{array}$ & $\begin{array}{l}\text { Rabbit polyclonal anti-p- } \\
\text { STAT-3 (Tyr705) ab (CST), } \\
\text { diluted 1:50 (IHC) }\end{array}$ & $\begin{array}{l}29.2 \%(7 / 24) \text { of grade II, } \\
57.1 \%(8 / 14) \text { of III and } \\
66.7 \%(4 / 6) \text { of IV showed } \\
\text { nuclear staining }\end{array}$ & $\begin{array}{l}\text { p-STAT-3 with } \\
\text { tumor grade }\end{array}$ & $\begin{array}{l}\text { p-STAT-3 with EGFR } \\
\text { in high grade gliomas }\end{array}$ & - \\
\hline $\begin{array}{l}\text { Brantley et al. [22] (HAs } \\
\text { grade IV cell lines/ HAs } \\
\text { grade IV } \\
\text { human brain tissues) }\end{array}$ & $\begin{array}{l}\text { - Anti-STAT-3 ab (CST), } \\
\text { diluted 1:1.000 (WB) } \\
\text { - Anti-p- STAT-3 (Tyr705) ab } \\
\text { (CST), diluted 1:1.000 (WB) } \\
\text { - Anti-p- STAT-3 (Ser727) ab } \\
\text { (CST), diluted 1:1000 (WB) }\end{array}$ & Not provided & - & $\begin{array}{l}\text { p-STAT-3 inhibited by } \\
\text { PIAS3 overexpression }\end{array}$ & - \\
\hline $\begin{array}{l}\text { Haybaeck et al. [14] (46 } \\
\text { HAs grade IV) }\end{array}$ & $\begin{array}{l}\text { Rabbit polyclonal anti- } \\
\text { STAT-1 ab (SCB), diluted } \\
\text { 1:1.000 (IHC) }\end{array}$ & $\begin{array}{l}85 \%(39 / 46) \text { showed cyto- } \\
\text { plasmic staining }\end{array}$ & - & - & - \\
\hline $\begin{array}{l}\text { Mizoguchi et al. [23] ( } 83 \\
\text { HAs: } 27 \text { grade III and } 55 \\
\text { IV) }\end{array}$ & $\begin{array}{l}\text { Mouse monoclonal anti-p- } \\
\text { STAT-3 (Tyr705) ab (CST), } \\
\text { diluted 1:20 (IHC) }\end{array}$ & $\begin{array}{l}56.4 \%(31 / 55) \text { of HAs } \\
\text { grade IV and } 55.6 \%(15 / 27) \\
\text { of HAs grade III showed } \\
\text { nuclear staining }\end{array}$ & $\begin{array}{l}\text { No correlation with } \\
\text { tumor grade }\end{array}$ & $\begin{array}{l}\text { p-STAT-3 with: } \\
\text { - EGFR and EGFRvIII } \\
\text { p-AKT }\end{array}$ & $\begin{array}{l}\text { p-STAT- } 3 \text { marginally predictive of } \\
\text { improved prognosis }\end{array}$ \\
\hline $\begin{array}{l}\text { Riemenschneider et al. } \\
\text { [24] (29 grade IV) }\end{array}$ & $\begin{array}{l}\text { Mouse monoclonal anti-p- } \\
\text { STAT-3 (Ser727) ab (CST), } \\
\text { diluted 1:2.000 (IHC) }\end{array}$ & Not provided & - & $\begin{array}{l}\text { p-AKT high and low } \\
\text { expression regions } \\
\text { similar p-STAT-3 } \\
\text { activation levels }\end{array}$ & - \\
\hline $\begin{array}{l}\text { Wang et al. [25] (128 HAs: } \\
9 \text { grade II, } 49 \mathrm{III} \text { and } 70 \mathrm{IV})\end{array}$ & $\begin{array}{l}\text { Mouse monoclonal anti-p- } \\
\text { STAT-3 (Tyr705) ab (CST), } \\
\text { diluted 1:100 (IHC) }\end{array}$ & $\begin{array}{l}8.9 \%(11 / 124) \text { showed } \\
\text { nuclear staining }\end{array}$ & $\begin{array}{l}\text { No correlation with } \\
\text { tumor grade }\end{array}$ & - & - \\
\hline $\begin{array}{l}\text { Weissenberger et al. [26] } \\
\text { (HAs) }\end{array}$ & $\begin{array}{l}\text { - Polyclonal anti-STAT-3a } \\
\text { ab (SCB), diluted 1:400 for } \\
\text { IHC and 1:1.000 for WB } \\
\text { - Polyclonal anti-p-STAT-3 } \\
\text { (Tyr705) ab (SCB), diluted } \\
\text { 1:200 for IHC and 1:1.000 } \\
\text { for WB }\end{array}$ & $\begin{array}{l}\text { Nuclear in grade II HAs and } \\
\text { nuclear and membranous in } \\
\text { grade IV HAs }\end{array}$ & $\begin{array}{l}\text { p-STAT-3 with } \\
\text { tumor grade }\end{array}$ & - & - \\
\hline
\end{tabular}

Abbreviations: AAs: Anaplastic Astrocytomas; ab: antibody; CST: Cell Signaling Technology (Beverly, MA) ; HAs: Human Astrocytomas (grades II-IV); IHC: Immunohistochemistry; KPS: Karnofsky Performance Status; MVD: Microvessel Density; OGs: Oligodendrogliomas; SCB: Santa Cruz Biotechnology; VEGF: Vascular Endothelial Growth Factor; WB: Western Blot

Table 1: Summary of reports investigating the role of STAT proteins and their activated forms (p-STAT) in astrocytomas.

often observed in mixed oligoastrocytomas, followed by GBM and anaplastic astrocytomas and the lowest in low-grade astrocytomas followed by oligodendrogliomas.

A point of disagreement between the reports dealing with the role of p-STAT-3 presence in gliomas is the association or not with the progression of the disease. The results of three different reports $[18,23,25]$ which showed that $\mathrm{p}$-STAT-3 expression was essentially identical between low-grade astrocytomas and GBM (unrelated to histologic grade), concluded that activation of STAT-3 is not a hallmark of tumor progression. On the other hand, some other reports $[17,19,20,21,26]$, found the expression of p-STAT-3 to correlate with progression of malignancy in gliomas. Abou-Ghazal et al. [19] did not find any immunostaining of p-STAT-3 in low-grade astrocytomas, whereas $53 \%$ of grade III astrocytomas, as well as 53\% of GBM or gliosarcomas expressed p-STAT-3. Despite that the incidence of p-STAT-3 expression was similar between grade III astrocytomas and GBM, the number of cells within the gliomas that expressed p-STAT-3 increased. It is noteworthy that the latter group for their statistical analysis considered the number of positive cells in every case instead of positive cells percentage.

Piperi et al. [17] found a perinecrotic distribution of p-STAT-3 expression. Their statistical analysis, except the correlation of STAT- 
3 activation with tumor grade, denoted a strong correlation of this activation with the presence and/or extent of necrosis. Moreover, as discussed previously, the "extra" membranous staining found in GBM by Weissenberger et al. [26] was detected in neoplastic cells situated at the margin of necrosis.

It is known that STAT-3 modulates oncogenesis inducing, inter alia, angiogenesis. In the report of Piperi et al. [17], p-STAT-3 expression was observed in some inflammatory cells around vessels and in endothelial cells of neo-synthesized vessels. Hypoxia appeared to account for the increased levels of p-STAT-3 in GBM in this study. In the same context, they showed a positive association between expression of p-STAT-3 and microvessel density, suggesting an implication of this protein in angiogenesis, or with high shape factor values, denoting an increase in intraluminal pressure possibly explained by a retarded blood flow within tumor due to an irregular vascular network. On the other hand, Lo et al. [21] observed that the vascular endothelial growth factor (VEGF) is expressed in human malignant glioma cells with hyperactive STAT-3. Moreover, as in the report of Piperi et al. [17], Schaefer et al. [27] observed that tumor endothelial cells within gliomas contained constitutively activated STAT-3, which resulted in the activation of VEGFR-2. All these findings, together with the high levels of VEGF expressed by malignant gliomas, suggest that gliomas with activated STAT-3 may have a VEGF/VEGFR autocrine loop to facilitate angiogenesis during gliomagenesis.

An attempt to correlate the expression of p-STAT-3 in gliomas with the immune response of the patients was taken by Abou-Ghazal et al. [19]. They found a strong association between expression of p-STAT-3 and the number of $\mathrm{CD}^{+}$glioma-infiltrating cells. They claimed that the presence of infiltrating $\mathrm{T}$ cells does not correlate with their functional activity, since p-STAT-3 is known to suppress the immune response. Moreover, the same group failed to find a correlation between p-STAT-3 expression and FoxP3 $^{+}$Treg infiltration, suggesting that some additional factors may be needed for the induction of FoxP3.

Correlations of STAT and p-STAT proteins with the "natural" inhibitors of the JAK-STAT pathway will be discussed in next section. In the report of Caldera et al. [20], no association was observed between p-STAT-3 and Ki67/MIB.1 labeling index, which led them to suggest that the relationship between p-STAT-3 and proliferation is indirect since it results through inhibition of apoptosis by Bcl-2 activation. Moreover, the statistical analysis of the same group failed to reveal any correlation of activated STAT- 3 and EGFR status. On the contrary, Lo et al. [21] found that EGFR frequently coexist with p-STAT-3 in high-grade glioma. In the same context, Mizoguchi et al. [23] denoted that p-STAT-3 correlated significantly with EGFRvIII but not with EGFRwt, concluding that these two receptors may affect distinct biologic signaling.

On the other hand, some reports looked for a possible relation of the activated form of STAT-3 with AKT protein and the MAPK pathway. Caldera et al. [20] found a significant correlation between p-AKT levels as measured by immunobloting and the immunohistochemical expression of p-STAT-3. Moreover, in agreement with this finding, Mizoguchi et al. [23] denoted a strong correlation of the activated forms of these two proteins and a coexpression in $97 \%$ of cases. Also, from the latter report no significant correlation emerged between p-STAT-3 and MAPK activation. Finally, Riemenschneider et al. [24], who used a particular way for the evaluation of immunohistochemistry by recording topographical distributions of expressed proteins within individual tumors, selected regions with high and low p-AKT expression. Within these selected regions low median expression differences for $\mathrm{p}$-STAT-3 were detected, whereas p-STAT-3 expression levels were not significantly correlated to AKT activation levels. The latter group explained this lack of correlation as consequence of the indirect interactions of these two molecules.

A recent report [16] investigated the impact of total STAT-3 in human gliomas. In $69 \%$ of cases, where they detected a nuclear and cytoplasmic expression of total STAT-3, they did not observed any significant statistical association with clinicopathological features, implying that these features may not alter total STAT-3 expression. On the contrary, they found that total STAT-3 expression was correlated to tumor grade and lower KPS (Karnofsky Performance Status).

The challenging part of this review is the clarification of the potential impact of STAT-3 and/or p-STAT-3 expression on glioma patients' survival. The importance of STAT-3 related to prognosis is very controversial. Caldera et al. [20] did not find any association between expression of p-STAT-3 and survival in GBM, whereas the univariate survival analysis of Piperi et al. [17] showed that p-STAT-3 overexpression predicts improved survival of GBM patients', since the median survival rate was 10 months for patients with p-STAT-3 overexpression compared to 6 months for those without protein overexpression. In the same context, Mizoguchi et al. [23] found that activation of STAT-3 was marginally attesting improved survival. On the contrary, the univariate survival analysis of Birner et al. [18] revealed that overexpression of p-STAT-3 was suggestive of worse survival (56\% of patients with no/low numbers of p-STAT-3-positive tumor cells versus only $40 \%$ of those with elevated numbers survived 1 year). Similar results were found by Abou-Ghazal et al. [19], where regardless of tumor pathology, the median survival time of patients lacking p-STAT-3 expression was higher than the overexpressors (34.6 vs. 20.1, respectively). Also, the latter group found similar differences within the group of GBM (10.7 for the expressors vs. 18.1 for the non-expressors). Despite the results of the latter group that lacked statistical significance due probably to the small sample size, in anaplastic astrocytomas (where the median survival time was 12.2 for the expressors vs. 34.6 for the non-expressors) p-STAT-3 emerged as a prognostic factor. Finally, Tu et al. [16] found that expression of STAT-3 was statistically correlated to worse prognosis.

In the multivariate survival analysis of Piperi et al. [17] and AbouGhazal et al. [19], p-STAT-3 did not retain its statistical importance, whereas the multivariate analysis of Birner et al. [18] for p-STAT-3 and the one of Tu et al. [16] for STAT- 3 revealed these proteins as independent prognostic factors.

The differences in the survival analysis among these studies could be in some way explained by the heterogeneous cohort used for the analysis, the employment of total versus activated STAT-3 expression, the p-STAT-3 expression level considered as positive for survival analysis, the use of the number of positive cells instead of the percentage [19], and finally the use of different cut-off points for the categorization of p-STAT-3 immunopositivity. Also, another possible explanation of this confusing data might be the complicated signaling network in which STAT-3 protein is implicated. The findings of several investigations could explain why in some cases STAT-3 protein is an indicator of better outcome and in others a prognostic factor of reduced survival. For example, STAT-3 expression during cortical development is associated with astrocyte differentiation and, thus, this could explain why is some cases it was associated with better prognosis [23]. Moreover, transient or continuous activation 
Citation: El Habr EA, Adamopoulos C, Levidou G, Samaras V, Zisakis A, et al. (2013) Implication of the JAK-STAT Pathway in Gliomagenesis: A Target for Therapy? J Neurol Disord 1: 112. doi:10.4172/2329-6895.1000112

Page 5 of 8

of STAT-3 could generate opposing effects such as proliferation or differentiation [18]. Finally, a dual role of STAT-3 has been proposed, PTEN deficiency, repression of IL-8 confers STAT-3 several tumor suppressive properties, while the opposite is provoked by EGFRVIII expression [28].

\section{The Inhibitors of STAT Proteins and their Implication in Gliomas}

In order to prevent malignant transformation, inhibition of JAKSTAT pathway is essential after cytokine stimulation. As mentioned in section 2, negative regulators of different classes contribute to inhibition of this pathway. The PIAS family, which includes PIAS1, PIAS3, PIASx and PIASy, are constitutively expressed in the nucleus [29]. PIAS1 and PIAS3 bind STAT-1 and STAT-3, respectively, in order depending on the "stimulator" of this protein. In the context of

to inhibit association with DNA, whereas the other two members of this family inhibit the STAT activity in an unknown manner [30]. On the other hand, SOCS family proteins (CIS (cytokine inducible SH2 domain containing protein) and SOCS1-SOCS7), inhibit cytokine signaling either by preventing STAT proteins to bind on receptoractivated residues or by targeting bound signaling proteins for proteasomal degradation [30].

Several studies [22,31-36] have investigated the role of SOCS and PIAS proteins in human gliomas (Table 2). Brantley et al. [22] denoted an absence of PIAS3 expression in human GBM tissues using two techniques (immunoblotting and immunohistochemistry) and two different PIAS3 antibodies. On the contrary, Wang and Banerjee [36] (data not available), who examined fewer number of GBM tissues than the previous group and used a different antibody, detected PIAS3 expression in their specimens. Moreover, in the analysis of Brantley

\begin{tabular}{|c|c|c|c|c|c|}
\hline $\begin{array}{l}\text { Report (number } \\
\text { of cases and } \\
\text { grades) }\end{array}$ & Antibody used & $\begin{array}{l}\text { Immunostaining } \\
\text { percentage/protein } \\
\text { expression }\end{array}$ & $\begin{array}{l}\text { Correlations with } \\
\text { clinicopathological } \\
\text { features }\end{array}$ & Other correlations & Survival analysis \\
\hline $\begin{array}{l}\text { Korkolopoulou et } \\
\text { al. [31] ( } 91 \text { HAs: } \\
18 \text { grade II, } 8 \text { III } \\
\text { and } 65 \text { IV) }\end{array}$ & $\begin{array}{l}\text { - Rabbit polyclonal anti-SOCS3 ab (SCB), } \\
\text { diluted 1:100 (IHC) and 1:200 (WB) } \\
\text { - Mouse monoclonal anti-CXCR2 ab } \\
\text { (R\&D Systems), diluted 1:50 (IHC) and } \\
\text { 1:200 (WB) } \\
\text { - Rabbit monoclonal anti-p-STAT-3 } \\
\text { (Tyr705) ab (CST), diluted 1:2.000 (WB) }\end{array}$ & $\begin{array}{l}92.4 \%(84 / 91) \text { showed } \\
\text { cytoplasmic and/or mem- } \\
\text { branous staining }\end{array}$ & $\begin{array}{l}\text { SOCS3 with: } \\
\text { - tumor grade } \\
\text { present/extent of } \\
\text { necrosis }\end{array}$ & $\begin{array}{l}\text { SOCS3 with: } \\
\text { - IL-8 } \\
\text { - VEGF } \\
\text { - MVD }\end{array}$ & $\begin{array}{l}\text { Increased SOCS3 } \\
\text { expression associated } \\
\text { with a worse prognosis }\end{array}$ \\
\hline $\begin{array}{l}\text { Lindemann et al. } \\
\text { [32] (40 HAs: } 3 \\
\text { grade II, } 4 \text { III and } \\
33 \text { IV/20 other } \\
\text { gliomas) }\end{array}$ & $\begin{array}{l}\text { - Mouse monoclonal anti-EGFR ab (Do), } \\
\text { diluted 1:25 (IHC) } \\
\text { - Mouse monoclonal anti-p-STAT-3 } \\
\text { (Tyr705) ab (CST), diluted 1:500 (WB) } \\
\text { - Rabbit polyclonal anti-p-MAPK ab } \\
\text { (CST), diluted 1:500 (WB) } \\
\text { - Rabbit monoclonal anti-p-AKT ab (CST), } \\
\text { diluted 1:1.000 (WB) } \\
\text { - Rabbit polyclonal anti-p-FAK ab (CST), } \\
\text { diluted 1:500 (WB) }\end{array}$ & Not provided & - & $\begin{array}{l}\text { SOCS3 hypermethylation } \\
\text { with: } \\
\text { - lower EGFR gene copy } \\
\text { - lower EGFR expression } \\
\text { SOCS3 depletion with: } \\
\text { - increased STAT-3 } \\
\text { phosphorylation } \\
\text { - increased FAK } \\
\text { phosphorylation } \\
\text { - glioma cell invasion }\end{array}$ & - \\
\hline $\begin{array}{l}\text { Martini et al. [33] } \\
\text { (46 HAs grade } \\
\text { IV) }\end{array}$ & - & - & $\begin{array}{l}\text { No significant cor- } \\
\text { relation between } \\
\text { SOCS1-3 hypermeth- } \\
\text { ylation and clinico- } \\
\text { pathological data }\end{array}$ & $\begin{array}{l}\text { SOCS1-3 hypermethylation } \\
\text { with low mRNA levels of } \\
\text { corresponding genes }\end{array}$ & $\begin{array}{l}\text { - SOCS3 hyper-methyla- } \\
\text { tion with shorter OS } \\
\text { - Multivariate analysis: } \\
\text { SOCS3 methylation } \\
\text { status as an independent } \\
\text { prognostic factor }\end{array}$ \\
\hline $\begin{array}{l}\text { Brantley et al. } \\
\text { [22] (grade IV cell } \\
\text { lines/HAs grade } \\
\text { IV tissues) }\end{array}$ & $\begin{array}{l}\text { - Anti-PIAS3 (COOH terminus) ab (SCB), } \\
\text { diluted 1:300 (IHC) } \\
\text { - Anti-p-PIAS3 (NH2 terminus) ab } \\
\text { (Abgent), diluted 1:300 (IHC) and 1:100 (WB) } \\
\text { - Anti-p-SOCS3 ab (Zymed), diluted 1:500 } \\
\text { (WB) }\end{array}$ & $\begin{array}{l}\text { - } 11 \% \text { (4/35) of grade } \\
\text { IV tissue had PIAS3 } \\
\text { expression (confirmed } \\
\text { by second ab) measured } \\
\text { by WB } \\
\text { - No positive reactivity for } \\
\text { PIAS3 in grade IV tissue } \\
\text { measured by IHC } \\
\text { - Constitutive PIAS3 } \\
\text { expression in primary } \\
\text { and commercial grade IV } \\
\text { cell lines } \\
\text { - } 89 \% \text { (16/18) of grade } \\
\text { IV tissue had SOCS3 } \\
\text { expression measured } \\
\text { by WB }\end{array}$ & - & $\begin{array}{l}\text { Lack of PIAS3 expression } \\
\text { with: } \\
\text { - STAT-3 activation } \\
\text { - increased proliferation } \\
\text { Overexpression of PIAS3 } \\
\text { with: } \\
\text { - STAT-3 inhibition } \\
\text { - survivn and Bcl-xL inhibition } \\
\text { - ecreased proliferation } \\
\text { - SOCS3 expression }\end{array}$ & - \\
\hline $\begin{array}{l}\text { Zhou et al. [35] } \\
\text { (10 HAs grade } \\
\text { IV cell lines/12 } \\
\text { HA grade IV and } \\
\text { normal human } \\
\text { brain tissues) }\end{array}$ & $\begin{array}{l}\text { - Rabbit polyclonal anti-SOCS3 ab [40], at } \\
\text { a concentration of } 2.5 \mu \mathrm{g} / \mathrm{mL} \text { (IHC) } \\
\text { - Anti-AKT ab (NEB) (WB) } \\
\text { - Anti-ERK ab (SCB) (WB) } \\
\text { - Anti-STAT-3 ab (SCB) (WB) }\end{array}$ & $\begin{array}{l}\text { Constitutive SOCS3 } \\
\text { protein expression in: } \\
\text { - grade IV cell lines by } \\
\text { WB } \\
\text { - } 100 \%(12 / 12) \text { grade IV } \\
\text { primary tissue sample } \\
\text { (cytoplasmic, around } \\
\text { blood vessels and } \\
\text { necrosis) by IHC }\end{array}$ & - & $\begin{array}{l}\text { SOCS1 repression with: } \\
\text { - radioresistance } \\
\text { - increased p-ERK1/2 levels } \\
\text { SOCS3 expression with: } \\
\text { - STAT-3 activation } \\
\text { - radioresistance } \\
\text { - increased p-ERK1/2 levels }\end{array}$ & - \\
\hline
\end{tabular}

Abbreviations: ab: antibody; CST: Cell Signaling Technology (Beverly, MA); Do: Dako (Hamburg, Germany); HAs: Human Astrocytomas (grades II-IV); IHC Immunohistochemistry; MVD: Microvessel Density; NEB: New England Biolabs (Ipswich, MA); OS: Overall Survival; p-ERK1/2: Phosphorylated Extracellular-SignalRegulated Kinase; VEGF: Vascular Endothelial Growth Factor; WB: Western Blot

Table 2: Summary of reports investigating the role of STAT inhibitors in gliomas. 
et al. [22], similar levels of PIAS3 mRNA expression were found between normal brain and GBM tissues, which were not the case for the levels of PIAS3 protein expression. The latter group suggested that these differences may be a consequence of posttranslational changes to PIAS3 protein (e.g. degradation by the ubiquitin-proteasome system). In the same context, the same group, using siRNA, provoked PIAS3 knockdown in GBM cells, in order to reproduce the in vivo loss observed in GBM tissue. Despite their observation of a significant increase in cell proliferation, p-STAT-3 levels were stable. On the contrary, when they overexpressed PIAS 3 in the cells, they denoted a significant inhibition of several cellular functions stimulated by STAT-3. All these findings led them to conclude that PIAS3 protein expression may negatively affect gliomagenesis. In agreement with these observations, Ehrmann et al. [34], treated cells from GBM classical cell lines with PPARy (peroxisome proliferator activated receptor) agonist ciglitaztone, which has been shown to suppress JAK-STAT pathway, and remarked an increase expression of PIAS3. Finally, Brantley et al. [22] showed that PIAS3 may affect other signaling pathways than the JAK-STAT, since they found that PIAS3 overexpression inhibits NF- $\mathrm{kB}$ signaling.

Despite the known negative role of SOCS3 in STAT-3 activation, in the literature its role in tumorigenesis is unclear. In some cases it has been nominated as a tumor suppressor, whereas in others as a promoter of malignant transformation. Two independent reports $[22,35]$ found a constitutive protein expression of SOCS3 in GBM, whereas Korkolopoulou et al. [31] detected SOCS3 in different grades of astrocytomas with the expression of the latter correlating with tumor progression. SOCS3 expression was detected by immunoblotting in GBM cell lines [35] and in fresh-frozen tissue specimens [31], and by immunohistochemistry in primary GBM human tissues [35] and human astrocytoma tissues [31], whereas Brantley et al. [22] remarked an elevated SOCS3 expression in primary GBM human tissues by immunoblotting. As seen by the immunohistochemical analysis, the immunopositive cells for SOCS3 had a cytoplasmic [31,35] and membranous [31] staining, and were detected in perivascular and in some cases in perinecrotic areas of GBM samples. This topographical localization could implicate SOCS3 expression in the regulation of angiogenesis and hypoxia signaling pathway. Moreover, Korkolopoulou et al. [31] observed a similar perinecrotic distribution and a strong association of SOCS3, IL-8 and VEGF expression, suggesting that hypoxia could commonly influence the pathways regulating these proteins. It is noteworthy that Zhou et al. [35] also found SOCS3 mRNA expression in all GBM cell lines; SOCS3 protein and mRNA expression were found to depend on STAT activation [35], whereas PIAS3 overexpression reduced SOCS3 mRNA levels [22]. Moreover, ERK1/2 activation was found to correlate with SOCS3 expression, the overexpression of which seemed to confer neoplastic cells a protection against ionizing radiation [35]. Finally, Korkolopoulou et al. [31] failed to observe the expected negative correlation between STAT-3 activation and SOCS3 expression, suggesting that other mechanisms SOCS3-independent could affect the activation of the former.

Except of SOCS3 mRNA and protein expression, some groups investigated the methylation status of the promoter of SOCS3 gene. Zhou et al. [35], who detected both mRNA and protein expression of SOCS3 in GBM, found that the promoter of the corresponding gene was unmethylated, a fact that confirmed their findings and proved that SOCS3 gene is expressed in GBM cell lines. On the contrary, two other reports $[32,33]$ found SOCS3 gene to be epigenetically silenced in gliomas. Both reports $[32,33]$, showed an inverse correlation between SOCS3 promoter hypermethylation and SOCS3 mRNA levels. Lindemann et al. [32] found that this hypermethylation is related to tumor histologic type, since primary GBM had the lowest frequency of hypermethylation followed by diffuse, anaplastic and secondary GBM, whereas mixed oligoastrocytomas and oligodendrogliomas had the highest percentage. It is noteworthy that the same group did not detect any mutation in exon 2 of SOCS3 gene in 60 examined cases. On the other hand, the statistical analysis of Martini et al. [33], the cohort of which was consisted of 46 GBM, failed to emerge any correlation of the hypermethylation status of SOCS3 with clinicopathological features, Ki67 labeling index, p53 mutation and the status of MGMT methylation; Lindemann et al. [32] showed that SOCS3 promoter hypermethylation was correlated with lower EGFR gene copy as estimated by real-time PCR and with low EGFR expression as measured by immunohistochemistry, suggesting that EGFR activation and SOCS3 repression could be mutually exclusive. Moreover, the same group provoked SOCS3 depletion in U251 GBM cell line which resulted in a strong activation of STAT-3 and FAK on one hand, and in increase of glioma cell invasion on the other hand; Another point of confusion is the opposite findings of two groups, since Lindemann et al. [32] found SOCS3 depletion to provoke ERK1/2 activation, whereas Zhou et al. [35] noticed that SOCS3 protein activates ERK1/2.

Of some interest is the survival analysis of Martini et al. [33] who found SOCS3 hypermethylation to correlate with shorter overall survival (7.91 months for the hypermethylated cases versus 16.15 months for the unmethylated cases). In the multivariate analysis of the same group, SOCS3 methylation status was an independent prognostic factor of worse outcome. On the contrary, Korkolopoulou et al. [31] showed that enhanced SOCS3 expression was associated with shorter overall survival in the univariate analysis but not in multivariate.

Regarding SOCS1 gene methylation status, Zhou et al. [35] found that in 7 out of $10 \mathrm{GBM}$ cell lines the former was down-regulated since it was hypermathylated and in the other three identical levels of methylated and unmethylated sequences were found. In the same context, the same group found that SOCS1 mRNA was absent in all GBM cell lines. Similar findings had the group of Martini et al [33], where $24 \%$ of examined cases were found to be hypermethylated for this gene and had reduced SOCS1 mRNA levels. Moreover, the statistical analysis of the latter group failed to find any correlation of SOCS1 methylation status with clinicopathological features, Ki67 labeling index, p53 mutation, and the status of MGMT methylation and patients' survival; Zhou et al. [35] tested the effect of SOCS1 gene repression and observed that in GBM U87 cell lines, cells expressing SOCS1 protein were more sensitive to ionizing radiation, which could be due to reduction of activated ERK1/2 levels.

Finally, Martini et al. [33] detected a SOCS2 gene hypermethylation in $6.5 \%$ of examined cases, together with reduced SOCS2 mRNA levels, but their statistical analysis did not emerge any correlation of SOCS2 methylation status with clinicopathological features, Ki67 index, mutated p53, MGMT methylation and patients' survival.

\section{Therapeutic Approaches Targeting JAK-STAT Pathway in Gliomas}

The transcription factors STAT-3 and/or NF- $\kappa \mathrm{B}$ present very promising targets for cancer therapy since they are the converging points of multiple pathways linking cancer-associated inflammation and immunosuppression. STAT-3 inhibitors with anti-tumor activities 
Citation: El Habr EA, Adamopoulos C, Levidou G, Samaras V, Zisakis A, et al. (2013) Implication of the JAK-STAT Pathway in Gliomagenesis: A Target for Therapy? J Neurol Disord 1: 112. doi:10.4172/2329-6895.1000112

include small molecule compounds produced from structure-based design or random screening, oligonucleotides (antisense RNA and siRNA) and natural products (resveratrol, curcumin). However, clinical trials with direct targeting of JAK-STAT pathway in glioma patients are rather limited.

A small molecule STAT-3 inhibitor, namely WP1066, able to access the central nervous system in mice and inducing potent immune response activation, has been tested in immune cells of GBM patients with potential of reversing immune tolerance at physiological doses [37]. This inhibitor which is a natural product (caffeic acid) has been shown to upregulate the production of costimulatory molecules in infiltrating macrophages of gliomas and to induce the expression of stimulatory cytokines as well as the proliferation of $\mathrm{T}$ cells. The potential use of WP1066 in immunotherapy in order to overcome the observed immunosuppression of glioma patients is currently under consideration.

Another pharmacological compound, AZD1480 capable of inhibiting JAK1/2, has been shown to efficiently reduce cell proliferation and enhance apoptosis in murine and human glioma cells [38]. In vitro experiments with the same inhibitor showed suppression of STAT-3 activation in the initial population of glioma cells forming GBM tumors. Furthermore, encouraging in vivo data were obtained when AZD1480 was tested in mice bearing intracranial GBM tumors by reducing tumor overgrowth and prolong animal survival suggesting the promising application of this agent in human studies [38]

Several tyrosine kinase inhibitors such as sunitinib and sorafenib that have been approved from US Food and Drug Administration, were also shown to indirectly inhibit STAT-3 resulting in inhibition of cell cycle and apoptosis of cancer cells $[39,40]$. Further evaluation of these compounds, elucidation of their exact mechanism of action and application in clinical trials of glioma patients remain open.

\section{Conclusion and Future Perspectives}

Activation of JAK-STAT pathway has emerged as a critical regulator of gliomagenesis implicated both in cancer cell growth and angiogenesis while enhancing underlying inflammation and immunosuppression characterizing glioma patients. These functions are attributed to the dual functions of STAT- 3 as tumor suppressor and oncogenic molecule based on tumor's genetic background (PTENdeficiency or expression of EGFRIII mutation, respectively) [41]. The development of STAT-3 inhibitors presents a current challenge and the aim of several studies with several classes of compounds being under investigation in human cancer models. However, the heterogeneity of glioma tumors demands a patient-tailored treatment with STAT-3 inhibitors being promising only in gliomas expressing EGFRvIII mutation where sensitization to chemotherapeutic agents can be successful [42].

On the contrary, STAT-3 inhibitors may prove harmful for PTENdeficient tumors since STAT-3 acts as a tumor suppressor regulated by PTEN and its inhibition will presumably potentiate tumor growth through IL-8 activation [28]. In this case, inhibitors acting upstream of STAT-3, targeting IL-8 or its receptor would be more efficient in reducing tumor growth and invasion.

Although additional studies are in demand in order to determine the significance of JAK-STAT pathway in the pathogenesis of gliomas, it is evident that novel treatment strategies should include primarily genotyping of tumors before use of STAT-3 or IL- 8 inhibitors along with standard surgical procedures, radiation and chemotherapy for efficient management of glioma patients.

\section{References}

1. Louis DN, Ohgaki H, Wiestler OD, Cavenee WK, Burger PC, et al. (2007) The 2007 WHO classification of tumours of the central nervous system. Acta Neuropathol 114: 97-109.

2. Rabinovich GA, Gabrilovich D, Sotomayor EM (2007) Immunosuppressive strategies that are mediated by tumor cells. Annu Rev Immunol 25: 267-296.

3. Chen L, Xuan J, Riggins RB, Clarke R, Wang Y (2011) Identifying cancer biomarkers by network-constrained support vector machines. BMC Syst Biol 5: 161.

4. Mandell JW (2008) Immunohistochemical assessment of protein phosphorylation state: the dream and the reality. Histochem Cell Biol 130: 465-471.

5. Murray PJ (2007) The JAK-STAT signaling pathway: input and output integration. J Immunol 178: 2623-2629.

6. Boudny V, Kovarik J (2002) JAK/STAT signaling pathways and cancer. Janus kinases/signal transducers and activators of transcription. Neoplasma 49: 349-355.

7. Rawlings JS, Rosler KM, Harrison DA (2004) The JAK/STAT signaling pathway. J Cell Sci 117: 1281-1283.

8. Hilton DJ (1999) Negative regulators of cytokine signal transduction. Cel Mol Life Sci 55: 1568-1577.

9. Hankey PA (2009) Regulation of hematopoietic cell development and function by Stat3. Front Biosci 14: 5273-5290.

10. Shuai K, Liu B (2003) Regulation of JAK-STAT signalling in the immune system. Nat Rev Immunol 3: 900-911.

11. Levy DE, Darnell JE Jr (2002) Stats: transcriptional control and biological impact. Nat Rev Mol Cell Biol 3: 651-662.

12. Goh KC, Haque SJ, Williams BR (1999) p38 MAP kinase is required for STAT1 serine phosphorylation and transcriptional activation induced by interferons. EMBO J 18: 5601-5608.

13. Stephanou A, Latchman DS (2005) Opposing actions of STAT-1 and STAT-3. Growth Factors 23: 177-182.

14. Haybaeck J, Obrist P, Schindler CU, Spizzo G, Doppler W (2007) STAT-1 expression in human glioblastoma and peritumoral tissue. Anticancer Res 27: 3829-3835

15. Gartsbein M, Alt A, Hashimoto K, Nakajima K, Kuroki T, et al. (2006) The role of protein kinase $\mathrm{C}$ delta activation and STAT3 Ser727 phosphorylation in insulin-induced keratinocyte proliferation. J Cell Sci 119: 470-481.

16. Tu Y, Zhong Y, Fu J, Cao Y, Fu G, et al. (2011) Activation of JAK/STAT signal pathway predicts poor prognosis of patients with gliomas. Med Oncol 28 15-23.

17. Piperi C, Samaras V, Levidou G, Kavantzas N, Boviatsis E, et al. (2011) Prognostic significance of IL-8-STAT-3 pathway in astrocytomas: correlation with IL-6, VEGF and microvessel morphometry. Cytokine 55: 387-395.

18. Birner P, Toumangelova-Uzeir K, Natchev S, Guentchev M (2010) STAT3 tyrosine phosphorylation influences survival in glioblastoma. J Neurooncol 100: 339-343.

19. Abou-Ghazal M, Yang DS, Qiao W, Reina-Ortiz C, Wei J, et al. (2008) The incidence, correlation with tumor-infiltrating inflammation, and prognosis of phosphorylated STAT3 expression in human gliomas. Clin Cancer Res 14: 8228-8235.

20. Caldera V, Mellai M, Annovazzi L, Valente G, Tessitore L, et al (2008) Stat3 expression and its correlation with proliferation and apoptosis/autophagy in gliomas. J Oncol.

21. Lo HW, Cao X, Zhu H, Ali-Osman F (2008) Constitutively activated STAT3 frequently coexpresses with epidermal growth factor receptor in high-grade gliomas and targeting STAT3 sensitizes them to Iressa and alkylators. Clin Cancer Res 14: 6042-6054.

22. Brantley EC, Nabors LB, Gillespie GY, Choi YH, Palmer CA, et al. (2008) Loss of protein inhibitors of activated STAT-3 expression in glioblastoma 
Citation: El Habr EA, Adamopoulos C, Levidou G, Samaras V, Zisakis A, et al. (2013) Implication of the JAK-STAT Pathway in Gliomagenesis: A Target for Therapy? J Neurol Disord 1: 112. doi:10.4172/2329-6895.1000112

Page 8 of 8

multiforme tumors: implications for STAT-3 activation and gene expression. Clin Cancer Res 14: 4694-4704.

23. Mizoguchi M, Betensky RA, Batchelor TT, Bernay DC, Louis DN, et al. (2006) Activation of STAT3, MAPK, and AKT in malignant astrocytic gliomas correlation with EGFR status, tumor grade, and survival. J Neuropathol Exp Neurol 65: 1181-1188.

24. Riemenschneider MJ, Betensky RA, Pasedag SM, Louis DN (2006) AKT activation in human glioblastomas enhances proliferation via TSC2 and S6 kinase signaling. Cancer Res 66: 5618-5623.

25. Wang $\mathrm{H}$, Wang $\mathrm{H}$, Zhang W, Huang HJ, Liao WS, et al. (2004) Analysis of the activation status of Akt, NFkappaB, and Stat3 in human diffuse gliomas. Lab Invest 84: 941-951.

26. Weissenberger J, Loeffler S, Kappeler A, Kopf M, Lukes A, et al. (2004) $\mathrm{IL}-6$ is required for glioma development in a mouse model. Oncogene 23 : 3308-3316.

27. Schaefer LK, Ren Z, Fuller GN, Schaefer TS (2002) Constitutive activation of Stat3alpha in brain tumors: localization to tumor endothelial cells and activation by the endothelial tyrosine kinase receptor (VEGFR-2). Oncogene 21: 2058-2065

28. de la Iglesia N, Konopka G, Lim KL, Nutt CL, Bromberg JF, et al. (2008) Deregulation of a STAT3-interleukin 8 signaling pathway promotes human glioblastoma cell proliferation and invasiveness. J Neurosci 28: 5870-5878.

29. Brantley EC, Benveniste EN (2008) Signal transducer and activator of transcription-3: a molecular hub for signaling pathways in gliomas. Mo Cancer Res 6: 675-684.

30. Wormald S, Hilton DJ (2004) Inhibitors of cytokine signal transduction. J Bio Chem 279: 821-824.

31. Korkolopoulou P, Levidou G, El-Habr EA, Adamopoulos C, Samaras V, et al. (2012) Expression of interleukin-8 receptor CXCR2 and suppressor of cytokine signaling-3 in astrocytic tumors. Mol Med 18: 379-388.

32. Lindemann C, Hackmann O, Delic S, Schmidt N, Reifenberger G, et al. (2011) SOCS3 promoter methylation is mutually exclusive to EGFR amplification in gliomas and promotes glioma cell invasion through STAT3 and FAK activation. Acta Neuropathol 122: 241-251.

33. Martini M, Pallini R, Luongo G, Cenci T, Lucantoni C, et al. (2008) Prognostic relevance of SOCS3 hypermethylation in patients with glioblastoma multiforme. Int J Cancer 123: 2955-2960.

34. Ehrmann J, Strakova N, Vrzalikova K, Hezova R, Kolar Z (2008) Expression of STATs and their inhibitors SOCS and PIAS in brain tumors. In vitro and in vivo study. Neoplasma 55: 482-487.

35. Zhou H, Miki R, Eeva M, Fike FM, Seligson D, et al. (2007) Reciprocal regulation of SOCS 1 and SOCS3 enhances resistance to ionizing radiation in glioblastoma multiforme. Clin Cancer Res 13: 2344-2353.

36. Wang L, Banerjee S (2004) Differential PIAS3 expression in human malignancy. Oncol Rep 11: 1319-1324.

37. Hussain SF, Kong LY, Jordan J, Conrad C, Madden T, et al. (2007) A nove small molecule inhibitor of signal transducers and activators of transcription 3 reverses immune tolerance in malignant glioma patients. Cancer Res 67 9630-9636.

38. McFarland BC, Ma JY, Langford CP, Gillespie GY, Yu H, et al (2011) Therapeutic potential of AZD1480 for the treatment of human glioblastoma. Mol Cancer Ther 10: 2384-2393.

39. Yang F, Van Meter TE, Buettner R, Hedvat M, Liang W, et al. (2008) Sorafenib inhibits signal transducer and activator of transcription 3 signaling associated with growth arrest and apoptosis of medulloblastomas. Mol Cancer Ther 7: 3519-3526.

40. Xin H, Zhang C, Herrmann A, Du Y, Figlin R, et al. (2009) Sunitinib inhibition of Stat3 induces renal cell carcinoma tumor cell apoptosis and reduces immunosuppressive cells. Cancer Res 69: 2506-2513.

41. de la Iglesia N, Konopka G, Puram SV, Chan JA, Bachoo RM, et al. (2008) Identification of a PTEN-regulated STAT3 brain tumor suppressor pathway. Genes Dev 22: 449-462.

42. Gariboldi MB, Ravizza R, Molteni R, Osella D, Gabano E, et al. (2007) Inhibition of Stat3 increases doxorubicin sensitivity in a human metastatic breast cancer cell line. Cancer Lett 258: 181-188. 